\title{
Carbon Footprint of Fruit Paste Technology
}

\author{
Magdalena Wróbel-Jędrzejewska*, Urszula Stęplewska, \\ Pawel Kuleta, Lukasz Przybysz, Elżbieta Polak \\ Prof. Wacław Dąbrowski Institute of Agricultural and Food Biotechnology \\ Frozen Food Technology and Refrigeration Department \\ Pilsudskiego 84, 92-202 Lodz, Poland
}

Received: 31 August 2015

Accepted: 15 October 2015

\begin{abstract}
The carbon footprint is one of the main indicators to assess the impact of human activity on the natural environment. The aim of this study was to determine the carbon footprint for the production technology of fruit paste. We selected homogenized strawberry paste because it had the largest share in production. Our study presents the methodology for calculating carbon dioxide emissions in order to assess and reduce greenhouse gas emissions generated by the given food technology. $\mathrm{CO}_{2}$ emissions were calculated for monthly and annual production, taking into account available data on production, material balances obtained, emission data collected, and assumed indices. It has been shown that the process of cold storage is a major factor influencing the level of $\mathrm{CO}_{2}$ emissions. Determining the carbon footprint of specific technology enables deliberate reduction of greenhouse gas emissions, which contributes to environmental protection.
\end{abstract}

Keywords: carbon footprint, food technology, fruit paste, $\mathrm{CO}_{2}$ emissions

\section{Introduction}

Access to food is an inalienable right. Although food production has increased in recent years, particularly in developing countries, more than one billion people suffer from chronic malnutrition. At the same time, excessive food production is observed in developed countries. The Food and Agriculture Organization (FAO) report from 2013, on the scale of food waste, informs us that every year we throw away 1.3 billion tons of food, which accounts for $1 / 3$ of the produced food suitable for consumption. Fruits and vegetables are wasted the most, of which a large part already is at the stage of cultivation, harvesting, and storage [1-3].

*e-mail: magdalena.jedrzejewska@ibprs.pl
Agriculture must feed an increasing number of people using less arable land. The problem of nutrition does not simply mean meeting basic human nutritional needs. An important issue is the protection of the environment during food production.

Climate change and global warming are recognized internationally as problems that require current countermeasures. Negative phenomena are mainly caused by emissions of greenhouse gases both from industry as well as other anthropogenic activities. Restoring ecological balance requires immediate action to reduce greenhouse gas emissions. Therefore, the European Union set a target of reducing greenhouse gas emissions by $20 \%$ by 2020 compared to 1990 .

The structure of carbon dioxide emissions of the TESCO network, according to the data, is as follows:

- $60 \%$ is the result of energy consumption in stores, offices and distribution centers 
- $19 \%$ is emitted by refrigeration equipment

- $12 \%$ comes from fuel consumption during transportation

- $7 \%$ is the use of natural and liquid gas

- $2 \%$ is business travel

Knowing what activities cause the greatest $\mathrm{CO}_{2}$ emissions, entrepreneurs can more precisely influence their reduction. First of all they introduce energy-efficient solutions, e.g., they apply renewable sources at the retail level [4-6].

Currently, large-scale actions are being taken in the agri-food industry to reduce emissions of carbon dioxide globally. An integral part of the agri-food industry is refrigeration and air conditioning, which provide the proper conditions for the production, processing, and storage of products. Assessment indices have been defined in order to clearly identify the disruptive impact of refrigerants on the earth's atmosphere [7-9]. These include:

ODP - ozone depletion potential - an index created to quantitatively assess the impact of the individual substances on the ozone layer. It is referred to the R11 refrigerant, considered as the unit value (ODP $=1)$.

HGWP: halocarbon global warming potential, introduced in order to determine the destructive impact of refrigerants on the atmosphere. It refers to the R11 refrigerant, considered as the unit value $(\mathrm{ODP}=1)$.

GWP: global warming potential - a metric used to quantify the effect of a given substance on the greenhouse effect. It compares the amount of heat retained by a specific gas mass to the amount of heat retained by the unit mass of carbon dioxide. GWP is determined for a specific time period, usually 100 years. GWP for $\mathrm{CO}_{2}$ is equal to 1 .

TEWI: total equivalent warming impact, an index that takes into account the direct ability of a factor to cause this effect and an indirect impact on its formation through energy consumption by the device used.

ITH: integral time horizon is the accepted time horizon of the effect of a substance (usually 100 years).

\section{Carbon Footprint}

Carbon footprint (CF) $[10,11]$ is one of the metrics evaluating the impact on the environment of a particular technology of agri-food product manufacture. It determines the amount of greenhouse gases emitted in connection with direct and indirect human activity. The carbon footprint includes emissions of all greenhouse gases (carbon dioxide, methane, nitrous oxide, hydrofluorocarbons, perfluorocarbons, sulfur hexafluoride) and is expressed in tons of carbon dioxide equivalent. CF can be determined with regard to persons, products, services, stores, workplaces, cities, and even entire countries. It allows us to compare different greenhouse gas emissions [12, 13]. According to the literature, the emission of $1 \mathrm{~kg}$ of $\mathrm{CO}_{2}$ occurs when:

- Driving $6 \mathrm{~km}$ by car (est. consumption 7.3 1/100 km)

- Traveling $12 \mathrm{~km}$ by train or bus

- Flying $2.2 \mathrm{~km}$
- Working at a computer $(60 \mathrm{~W})$ for $32 \mathrm{~h}$

- Producing five plastic bags or two bottles

- Producing 1/3 of a cheeseburger

Production of $1 \mathrm{kWh}$ of electricity equals the release of about $1 \mathrm{~kg}$ of $\mathrm{CO}_{2}$ into the atmosphere, while consuming 1 liter of gasoline by a car is associated with the emission of more than $2 \mathrm{~kg}$ of $\mathrm{CO}_{2}$. For comparison, a tree over its life span absorbs on average approx. $750 \mathrm{~kg} \mathrm{CO}$ through the processes of photosynthesis and biomass accumulation [14].

Determining the carbon footprint of specific technology enables deliberate reduction of greenhouse gas emissions, which contributes to environmental protection.

This article presents the methodology for calculating carbon emissions, plus assessing and reducing greenhouse gas emissions generated by exemplary food technology. We selected the production technology of semi-finished fruit paste, used as a filling for sweets and chocolates, as a base for the production of fruit jellies and gummy candies, or as an ice cream flavor additive. Analyzing the structure of the production, homogenized strawberry paste was selected to determine the carbon footprint because it had the largest share.

\section{Aim and Research Methodology}

The aim of the study was to determine the carbon footprint for the selected food product with particular emphasis on the refrigeration industry.

The approach to the analysis of the issue is presented as the research method. Basic data were collected during visits and interviews at the production plant. The identification and measurement of direct and indirect $\mathrm{CF}$ is of key importance for each food technology. Defining the boundaries and areas of measurement, and establishing the scheme of unit processes that forms them, are an important task aimed at integrating the carbon footprint of the product [15]. Carbon footprint maps of the products developed in this way facilitate the identification and measurement of carbon dioxide emissions in the whole technological chain.

The research methodology involved the following steps:

Table 1. Structure of the production in a facility.

\begin{tabular}{|c|c|}
\hline Type of paste & $\begin{array}{c}\text { Participation in production } \\
{[\%]}\end{array}$ \\
\hline homogenized strawberry & 55.8 \\
\hline homogenized cherry & 20.1 \\
\hline cherry with fruit pieces & 0.9 \\
\hline strawberry with fruit pieces & 2.6 \\
\hline blueberry with fruit pieces & 20.1 \\
\hline decorative strawberry & 0.3 \\
\hline lemon & 0.3 \\
\hline
\end{tabular}




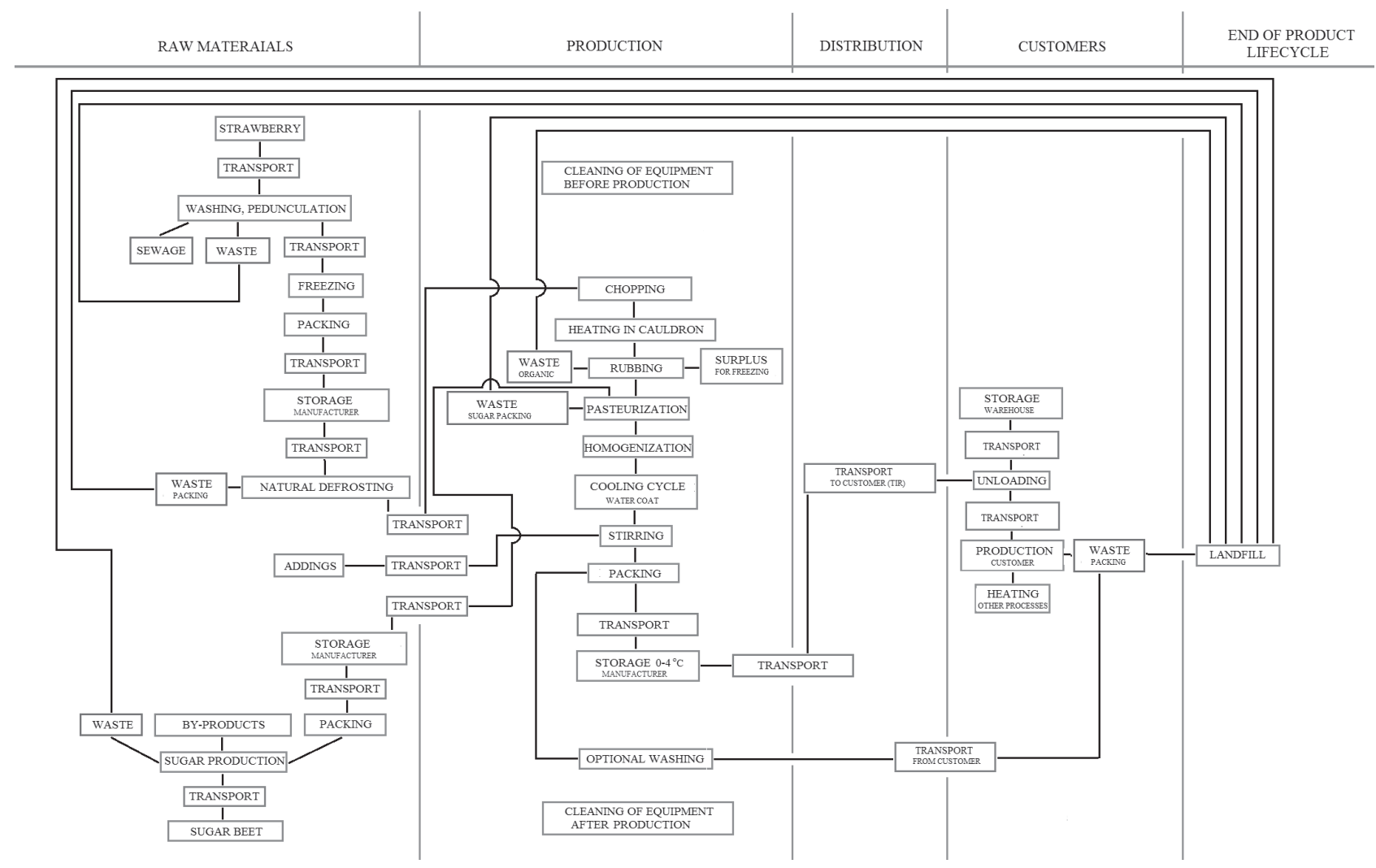

Fig. 1. Scheme of unit processes in the strawberry paste production cycle.

- Defining assumptions

- Analyzing production technologies at the production plant

- Selecting the production process

- Defining and determining unit processes in the production cycle

- Analyzing the data with respect to the volume of production, use of energy, and raw materials

- Selecting product for analysis and collecting emissions data

- Developing a CF calculator (spreadsheet)

- Calculating carbon footprint

Based on literature data [14], the following indices were used to calculate the carbon footprint:

- $\mathrm{CO}_{2}$ emissions in the production of $1 \mathrm{kWh}$ of energy $\left(1,000 \mathrm{~g} \mathrm{CO}_{2} / \mathrm{kWh}\right)$

- Eight liters of fuel combustion produces $19 \mathrm{~kg}$ of $\mathrm{CO}_{2}$ $\left(2,375 \mathrm{~g} \mathrm{CO}_{2} / 1\right)$

- An electric trolley consumes $10 \mathrm{kWh}(0.1 \mathrm{kWh} / \mathrm{km}$ per $100 \mathrm{~km})$

- A truck consumes 40 liters of fuel $(0.4 \mathrm{l} / \mathrm{km}$ per 100 $\mathrm{km})$

\section{Production Characteristics}

For the current study, the technology of production of semi-finished fruit products was selected. It was developed as part of the target project "Special fruit pastes
- semi-finished products for the manufacture of ice cream and frozen desserts," and received second prize from the minister of agriculture and food economy in 1997. Fruit pastes are currently produced by the IBPRS Department of Refrigeration Technology and Technique in Łódź for domestic and foreign customers. The structure of the department producing fruit pastes during an exemplary year is shown in Table 1. Analyzing this data, homogenized strawberry paste was selected to determine the carbon footprint, because it had the largest share of production.

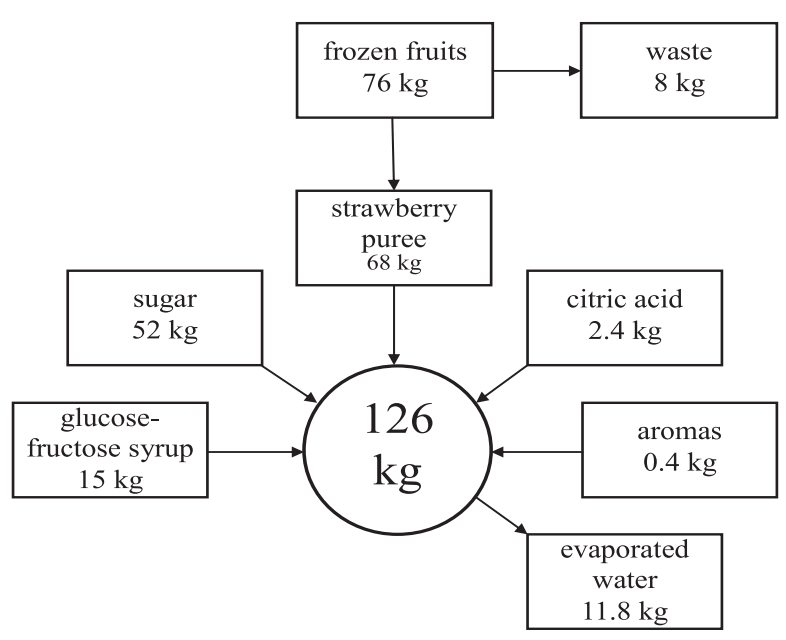

Fig. 2. Mass balance of raw materials for homogenized strawberry paste production. 
Table 2. Material balance for homogenized strawberry paste production.

\begin{tabular}{|c|c|c|c|c|c|c|}
\hline \multicolumn{7}{|c|}{ MATERIAL BALANCE } \\
\hline \multicolumn{4}{|c|}{ one production cycle } & \multirow{2}{*}{$\begin{array}{l}\text { amount of the } \\
\text { product in January } \\
{[\mathrm{kg}]}\end{array}$} & \multirow{2}{*}{$\begin{array}{l}\text { average amount } \\
\text { of product per } \\
\text { month }[\mathrm{kg}]\end{array}$} & \multirow{2}{*}{$\begin{array}{l}\text { amount of the } \\
\text { product per year } \\
{[\mathrm{kg}]}\end{array}$} \\
\hline raw material & $\begin{array}{l}\text { amount of raw } \\
\text { materials }[\mathrm{kg}]\end{array}$ & $\begin{array}{l}\text { amount of } \\
\text { waste }[\mathrm{kg}]\end{array}$ & $\begin{array}{l}\text { amount of water } \\
\text { evaporated }[\mathrm{kg}]\end{array}$ & & & \\
\hline strawberry & 76 & \multirow{5}{*}{8} & \multirow{5}{*}{11.8} & \multirow{5}{*}{1,692} & \multirow{5}{*}{$2,533.5$} & \multirow{5}{*}{30,402} \\
\hline sugar & 52 & & & & & \\
\hline $\begin{array}{l}\text { glucose-fructose } \\
\text { syrup } \\
\end{array}$ & 15 & & & & & \\
\hline citric acid & 2.4 & & & & & \\
\hline aromas & 0.4 & & & & & \\
\hline
\end{tabular}

Table 3. Emissions of $\mathrm{CO}_{2}$ generated in food technology of homogenized strawberry paste production per year.

\begin{tabular}{|c|c|c|c|c|c|c|c|c|}
\hline \multicolumn{7}{|c|}{ PRODUCTION } \\
\hline equipment & $\begin{array}{c}\text { nominal } \\
\text { power } \\
{[\mathrm{kW}]}\end{array}$ & $\begin{array}{c}\text { operating } \\
\text { time } \\
{[\mathrm{h}]}\end{array}$ & $\begin{array}{c}\text { power } \\
\text { consumption per } \\
\text { cycle [kWh] }\end{array}$ & $\begin{array}{c}\text { emission } \\
\text { of } \mathrm{CO}_{2} \\
\text { per cycle } \\
{[\mathrm{g}]}\end{array}$ & $\begin{array}{c}\text { number } \\
\text { of cycles } \\
\text { in January }\end{array}$ & $\begin{array}{c}\text { emission } \\
\text { of } \mathrm{CO}_{2} \\
{[\mathrm{~kg}]}\end{array}$ & $\begin{array}{c}\text { average } \\
\text { emission } \\
\text { of } \mathrm{CO}_{2} \text { per } \\
\text { month [ton] }\end{array}$ & $\begin{array}{c}\text { emission } \\
\text { of CO } \text { per }_{2} \\
\text { year [ton] }\end{array}$ \\
\hline mincer & 15.00 & 2.00 & 30.00 & 30,000 & 7 & 210.00 & 0.30 & 3.63 \\
\hline cauldron & 30.00 & 1.00 & 30.00 & 30,000 & 7 & 210.00 & 0.30 & 3.63 \\
\hline stirrer & 0.55 & 1.00 & 0.55 & 550 & 7 & 3.85 & 0.006 & 0.07 \\
\hline pump & 1.00 & 0.06 & 0.06 & 55 & 7 & 0.39 & 0.0006 & 0.007 \\
\hline controller & 0.6 & 0.06 & 0.03 & 33 & 7 & 0.23 & 0.0003 & 0.004 \\
\hline rubbing unit & 2.00 & 2.00 & 4.00 & 4,000 & 7 & 28.00 & 0.04 & 0.48 \\
\hline pasteurizer & 12.35 & 3.50 & 43.23 & 43,225 & 4 & 172.90 & 0.28 & 3.37 \\
\hline pasteurizer & 12.35 & 3.50 & 43.23 & 43,225 & 5 & 216.13 & 0.30 & 3.54 \\
\hline pasteurizer & 12.35 & 3.50 & 43.23 & 43,225 & 5 & 216.13 & 0.30 & 3.54 \\
\hline cooling tower & 3.75 & 3.50 & 13.13 & 13,125 & 7 & 91.88 & 0.13 & 1.59 \\
\hline cold rooms & 22.30 & 24.00 & - & - & $4,305.44$ & $4,305.44$ & 4.48 & 53.71 \\
\hline SUM & & & & & & $5,454.93$ & 6.13 & 73.58 \\
\hline
\end{tabular}

Table 4. Emissions of $\mathrm{CO}_{2}$ generated in transport for homogenized strawberry paste production.

\begin{tabular}{|c|c|c|c|c|c|c|c|c|}
\hline \multicolumn{9}{|c|}{ TRANSPORT } \\
\hline type & $\begin{array}{c}\text { power } \\
\text { consumption } \\
\text { per } 1 \mathrm{~km} \\
{[\mathrm{kWh}]}\end{array}$ & $\begin{array}{c}\text { fuel } \\
\text { consumption } \\
\text { per } 1 \mathrm{~km} \\
{[1]}\end{array}$ & $\begin{array}{l}\text { emission } \\
\text { of } \mathrm{CO}_{2} \text { per } \\
1 \mathrm{~km}[\mathrm{~kg}]\end{array}$ & $\begin{array}{l}\text { km per } \\
\text { cycle } \\
{[\mathrm{km}]}\end{array}$ & $\begin{array}{l}\text { number } \\
\text { of cycles } \\
\text { in January }\end{array}$ & $\begin{array}{c}\text { emission } \\
\text { of } \mathrm{CO}_{2} \\
{[\mathrm{~kg}]}\end{array}$ & $\begin{array}{c}\text { average } \\
\text { emission } \\
\text { of } \mathrm{CO}_{2} \text { per } \\
\text { month [ton] }\end{array}$ & $\begin{array}{l}\text { emission } \\
\text { of } \mathrm{CO}_{2} \text { per } \\
\text { year [ton] }\end{array}$ \\
\hline electric forklift & 0.1 & - & 0.1 & 0.1 & 2 & 0.02 & 0.00002 & 0.0003 \\
\hline TIR(strawberry) & - & 0.4 & 0.95 & 40 & 2 & 76 & 0.09 & 1.03 \\
\hline TIR (syrup) & - & 0.4 & 0.95 & 18 & 2 & 34.2 & 0.04 & 0.46 \\
\hline TIR (sugar) & - & 0.4 & 0.95 & 1 & 2 & 1.9 & 0.002 & 0.03 \\
\hline garbage disposal & - & 0.4 & 0.95 & 10 & 0 & 0 & 0 & 0 \\
\hline \multicolumn{6}{|c|}{ SUM } & 112.12 & 0.13 & 1.51 \\
\hline
\end{tabular}




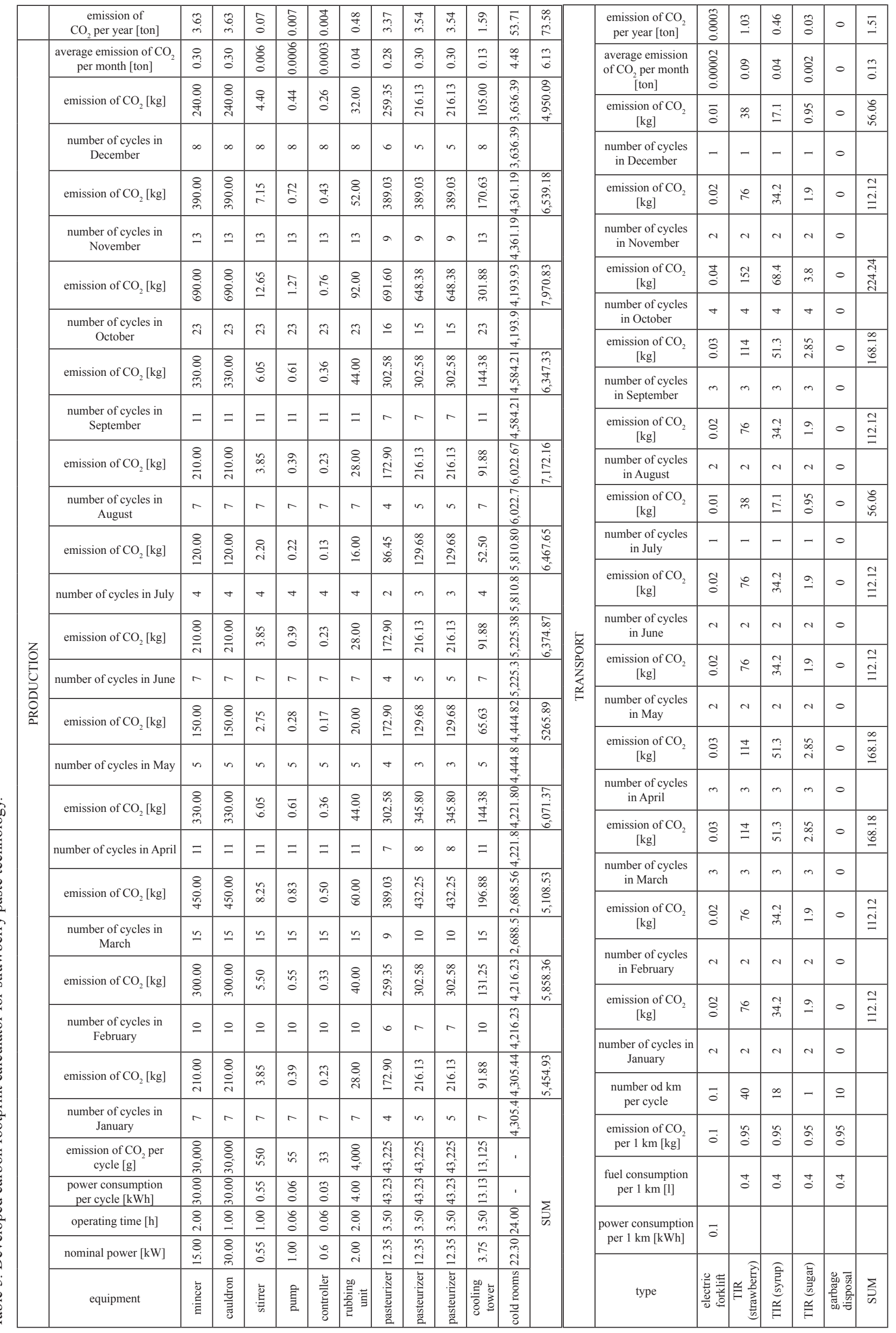




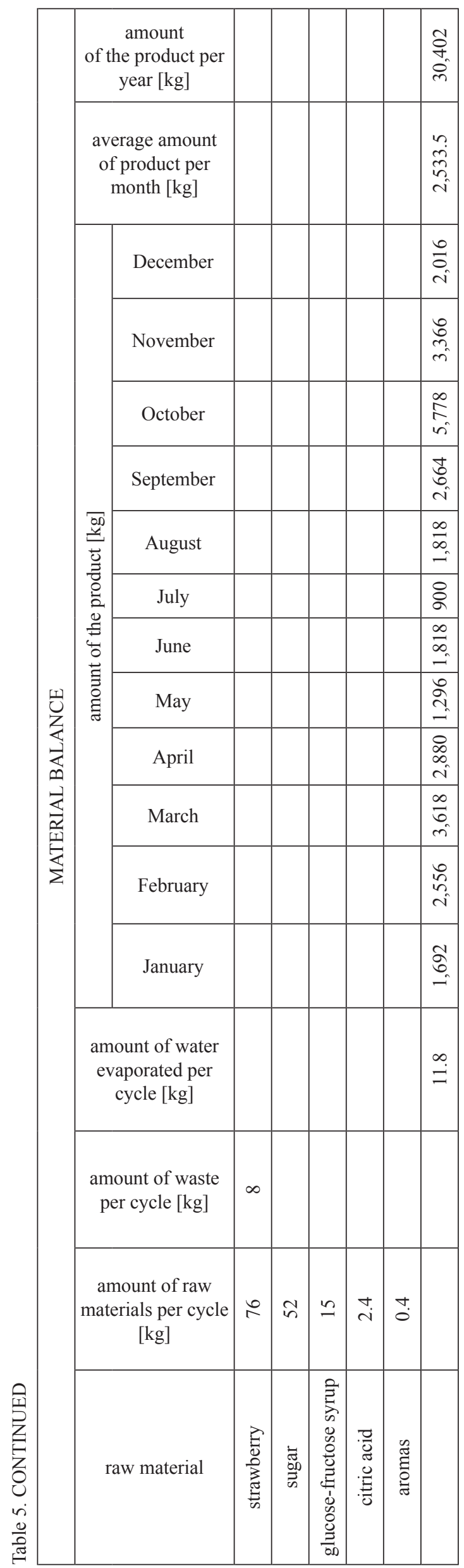

"Life cycle of strawberry paste" [16] was analyzed to define all unit processes included in production. Fig. 1 shows a diagram of the product life cycle. The following areas responsible for $\mathrm{CO}_{2}$ emissions were defined: raw materials, stages of the production process, distribution (transport), and recipients. The fruit paste production process was analyzed in detail. Each production cycle included the following steps: obtaining the right amount of raw materials from storage, fruit thawing, fruit grinding, fruit pureeing, combining ingredients and additives, homogenization and pasteurization, quality control, packaging, and storage. Mass balance of the homogenized paste production was performed based on the formula. These values are presented in Fig. 2.

\section{Assumptions for Carbon Footprint Calculation}

Based on the methodology of life cycle assessment (LCA) [17-22], methodology for calculating the CF was expressed in the following steps:

1. Defining the methodology: A global standard was introduced by the World Resources Institute (WRI) and the World Business Council for Sustainable Development (WBCSD) as part of the Greenhouse Gas Emission Protocol (GHGP) and in accordance with ISO 14064 (Greenhouse gases) Part 1: Specifications and guidance for quantification and reporting of greenhouse gases emissions and absorptions. The procedure described in the aforementioned materials contains detailed recommendations on the procedures for data collection, calculation, and reporting.

2. Establishing boundaries and scope of analysis: Defining which area will be subject to quantitative analysis, main production processes, auxiliary processes, etc.; how far the analysis should reach and how deep should it be; what type of emissions will be analyzed. It is recommended to define the boundaries and scope in such a way as to include the entire spectrum of emission sources; the more accurate the analysis, the more precise the determination of the carbon footprint.

3. Collection of emissions data: The most important process, dependent on the quality of the collected data and its accuracy. The information collected relates to direct and indirect emissions, including electricity consumption, emissions generated by suppliers (raw materials and additives), internal transport, and refrigerants. The created database of relevant information must have a specified level of accuracy record with a defined acceptable margin of error.

4. Carbon footprint calculation and its verification, including all stages of the production process.

5. Presentation of the analysis results and calculated $\mathrm{CF}$, with indication of the areas showing the highest emissions. 


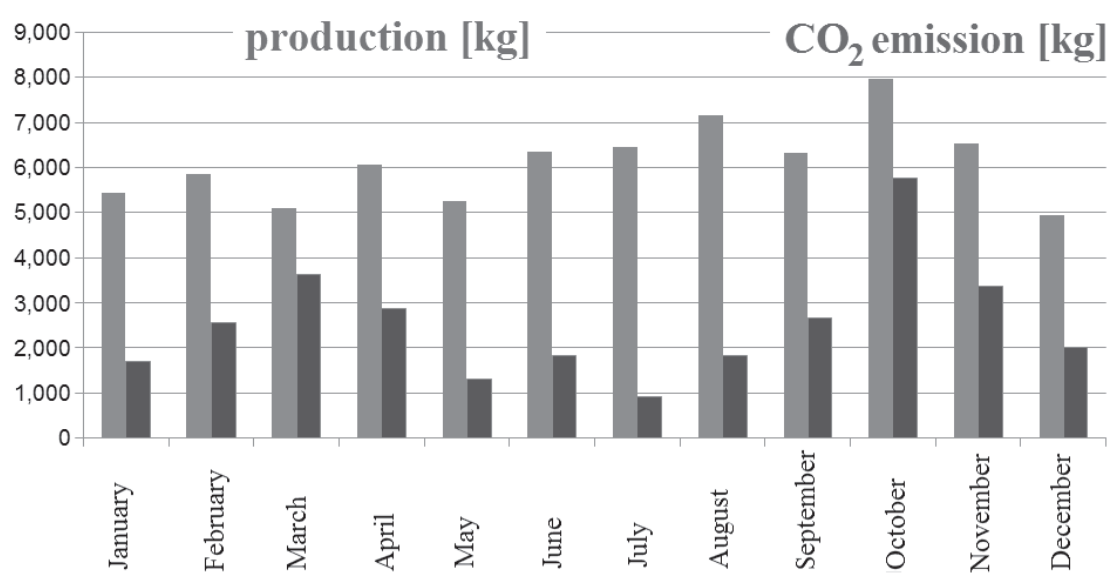

Fig. 3. Dependence of $\mathrm{CO}_{2}$ emissions from strawberry paste production.

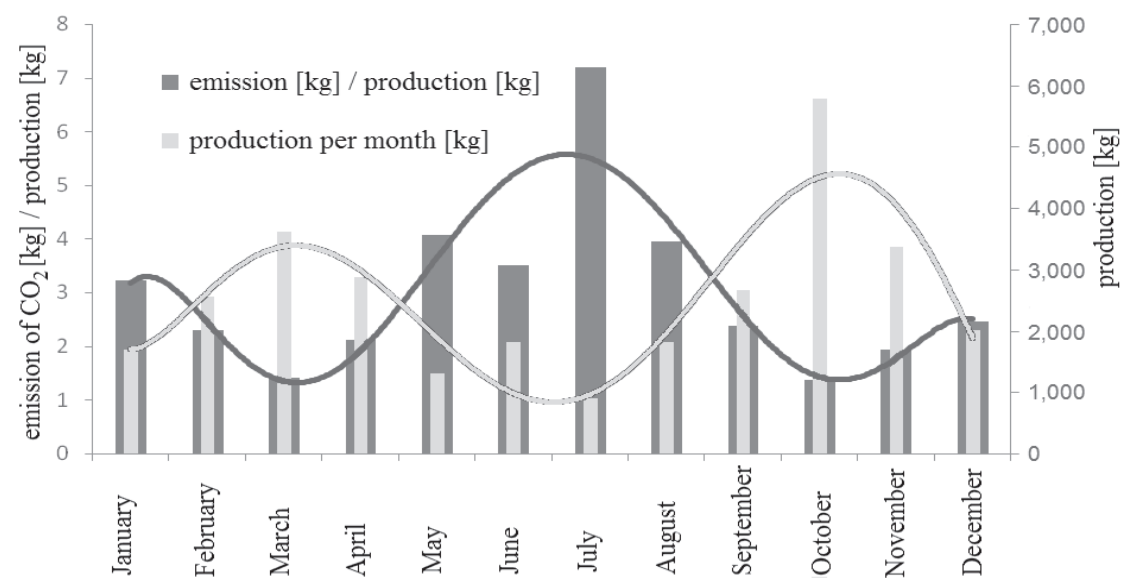

Fig. 4. Dependence of carbon footprint from monthly production.

\section{Carbon Footprint Determination of Selected Food Production}

On the basis of available data, an annual material balance was conducted for the production of homogenized strawberry paste (Table 2).

$\mathrm{CO}_{2}$ emissions were calculated for monthly and annual production, taking into account the available data

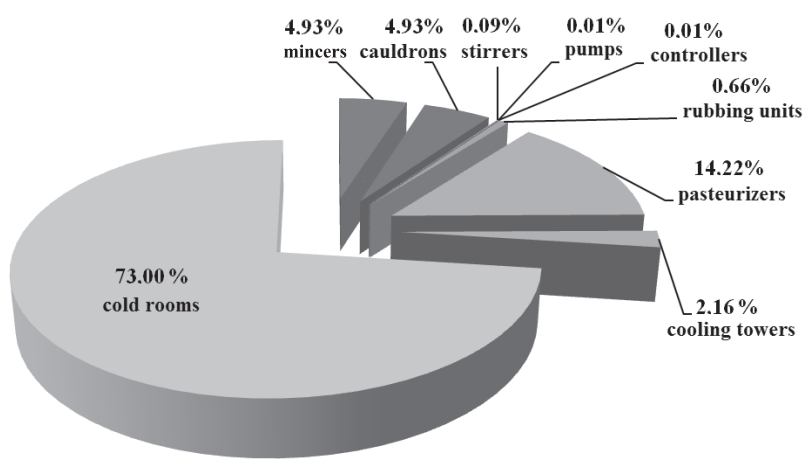

Fig. 5. Structure of $\mathrm{CO}_{2}$ emissions [\%] for annual strawberry paste production. on the production, material balances obtained, emissions data collected, and assumed indices. Table 3 shows the results only for the technological process, and Table 4 for transportation. The amount of $\mathrm{CO}_{2}$ emitted by transport was $1.51 \mathrm{t}$, which represented only $2 \%$ of emissions of the whole strawberry paste production cycle.

Considering all the listed steps and the calculated values of emissivity and raw material balances, the

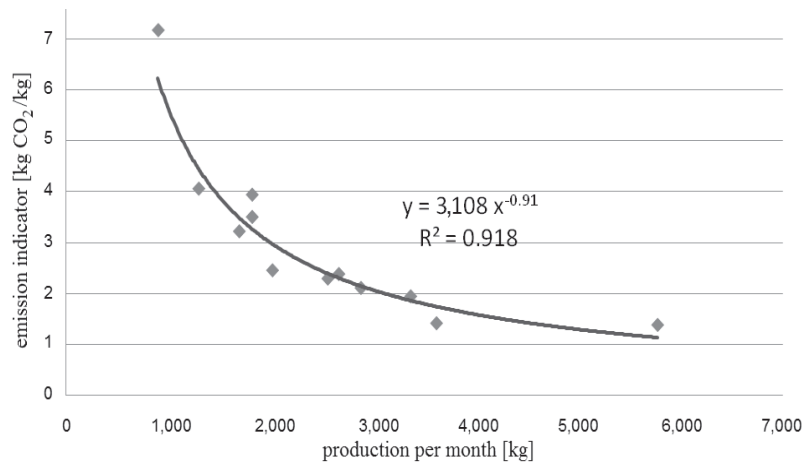

Fig. 6. Dependence of $\mathrm{CO}_{2}$ emissions indicator for monthly strawberry paste production. 
average product carbon footprint was calculated using the developed CF calculator (Table 5).

The averaged value of the CF index calculated on the basis of experimental data for the production of homogenized strawberry paste was $2.47 \mathrm{~kg} \mathrm{CO}_{2} / \mathrm{kg}$ of the product. This means that $2.47 \mathrm{~kg}$ of $\mathrm{CO}_{2}$ was emitted to the atmosphere during the production of $1 \mathrm{~kg}$ of paste.

A graph of dependence of this parameter on the volume of production during the year was prepared to better understand the emissivity results. By analyzing the data obtained, a certain tendency could be observed that despite the decline in production during the months of May, June, July, and August, $\mathrm{CO}_{2}$ emissions remained at a high level. This trend is due to the different external temperatures, as there is a higher cooling demand during these months (i.e., higher carbon dioxide emissions).

Fig. 4 presents a comparison of the carbon footprint and monthly production. Analyzing the results, an inverse relationship can be observed of the $\mathrm{CO}_{2}$ emissions index and paste production volume, thus intensification of the production will reduce $\mathrm{CO}_{2}$ emissions per product unit, i.e., the reduction of the carbon footprint.

In order to identify the area responsible for the highest emissions, a diagram was made of $\mathrm{CO}_{2}$ emission structure for the annual production of strawberry paste (Fig. 5), including the technological process (without transport). When analyzing this information, it was found that refrigerated storage of raw materials and semi-finished and finished products is the main factor determining $\mathrm{CO}_{2}$ emissions in the production process. It represents almost $73 \%$ of total emissions. Therefore, it is necessary to optimize the process of cold storage in order to reduce greenhouse gas emissions into the atmosphere. This can be achieved, among other ways, by rationalization of storage chamber use, reducing capacity, and maximizing use of their cooling areas.

Fig. 6 presents the change of $\mathrm{CO}_{2}$ emission index, compared to a monthly production of strawberry paste and dependence describing it as a power function. The emissivity of the technological process related to the amount of the final product produced can be determined using these results.

Following the $\mathrm{CF}$ calculation and identification of areas with the highest emissivity of a given food technology, appropriate measures should be taken in order to control and manage the emissions. This should result in a lower burden of carbon dioxide in the environment.

\section{Conclusions}

Conscious actions toward environmental protection include reduction of greenhouse gas emissions generated by the food industry into the atmosphere $[23,24]$. The first challenge in this direction is to determine the carbon footprint of technology and on this basis take measures to reduce greenhouse gas emissions.

The different methods of CF calculation for food products are presented in [25-30]. In most cases, the calculated carbon footprint covers all stages (from fields and pastures through the processing plant to the consumer) and determines the correlation between materials and processes. A proper example of this methodology is the carbon footprint (CF) of the croissant roll. This carbon footprint was $1.5 \mathrm{~kg} \mathrm{CO}_{2} / \mathrm{kg}$ of the product. Authors [28] stated that the largest effect on greenhouse gas emissions resulted from the processing and raw material links of the food chain (39.1 and 36.8\%, respectively). In other work [26], the CFs of cheese have been presented. The indicator was $9.88 \mathrm{~kg} \mathrm{CO}_{2} / \mathrm{kg}$ of the product. They also pointed out that emissions from the later part of the production chain from farm to retailer contributed less than $10 \%$ to total emissions from the production of cheese, with the largest contribution from the use of energy during manufacture at the dairy, including storage.

Thus, in order to compare the carbon footprints we need to calculate the indicator for the same production of a given product. In the case of the croissant roll, $\mathrm{CF}$ of production was $0.59 \mathrm{~kg} \mathrm{CO} / \mathrm{kg}$ of the product, and for the cheese it was below $0.99 \mathrm{~kg} \mathrm{CO} / \mathrm{kg}$ of the product. Part of our research was to calculate the carbon footprint index for the production of homogenized strawberry paste. Its averaged value was $2.47 \mathrm{~kg} \mathrm{CO} / \mathrm{kg}$ of the product.

Comparison of the obtained $\mathrm{CF}$ from the presented literature data showed that strawberry paste production is highly energy-consuming.

In our work, the amount of $\mathrm{CO}_{2}$ produced during transport was $1.51 \mathrm{t}$, which represented only $2 \%$ of emissions of the whole strawberry paste production cycle. Thus, the production process is primarily responsible for emissions.

A significant impact of climatic conditions was observed on the carbon footprint indicator, resulting from changes in external temperatures. Emission volume of carbon dioxide per unit of product is dependent largely on the external temperature in a given month, while to a lesser extent on the production volume. The main factor determining $\mathrm{CO}_{2}$ emissions in the production process was refrigerated storage of raw materials and semi-finished and finished products, which accounted for almost $73 \%$ of total emissions. The process of cold storage is a major factor affecting the carbon footprint of the technology tested.

Rationalization of the use of storage chambers and maximizing use of their cooling area will optimize the process of cold storage. These actions will be aimed at reducing the carbon footprint of food technology.

\section{References}

1. JAMES S.J., JAMES C. The food cold-chain and climate change. Food Res. Int. 43, 1944, 2010.

2. MIRAGLIA M., MARVIN H.J.P., KLETER G.A., BATTILANI P., BRERA C., CONI E. Climate change and food safety: An emerging issue with special focus on Europe. Food Chem. Toxicol. 47, 1009, 2009.

3. REES W.E. Footprint: our impact on Earth is getting heavier. Nature 420, 267, 2002.

4. HEDDEGHEM W., VEREECKEN WILLEM., COLLE D., PICKAVET M., DEMEESTER P. Distributed computing 
for carbon footprint reduction by exploiting low-footprint energy availability. Future Gener. Comp. Sy. 28 (2), 405, 2012.

5. LARSENA H., SOllia C., PETTERSENA J. Supply chain management how can we reduce our energy/climate footprint? Energy Procedia 20, 354, 2012.

6. LAGUERRE O., HOANG H.M., FLICK D. Experimental investigation and modelling in the food cold chain: Thermal and quality evolution. Trends Food Sci. Tech. 29 (2), 87, 2013.

7. OZAWA-MEIDA L., BROCKWAY P., LETTEN K., DAVIES J., FLEMING P. Measuring carbon performance in a UK University through a consumption-based carbon footprint. J. Clean. Prod. 56, 185, 2013.

8. PADGETT J.P., STEINEMANN A.C., CLARKE J.H., VANDENBERGH M.P. A comparison of carbon calculators. Environ. Impact Assess. Rev. 28, 106, 2008.

9. SUNDARAKANI B., DE SOUZA R., GOH M., WAGNER S.M., MANIKANDAN S. Modeling carbon footprints across the supply chain. Int. J. Production Economics $\mathbf{1 2 8}$ (1), 43, 2010.

10. AUNG M.M., CHANG J. Traceability in a food supply chain: Safety and quality perspectives. Food Control 39, 172, 2014.

11. AICHELE R., FELBERMAYR G. Kyoto and the carbon footprint of nations. J. Environ. Econ. Manage. 63 (3), 336, 2012.

12. WIEDMANN T., BARRETT J. A review of the ecological footprint indicator -perceptions and methods. Sustainability 2, 1645, 2010.

13. WIEDMANN T., MINX J. A definition of 'carbon footprint' in: Pertsova C.C. Ecological Economics Research Trends. Nova Science Publishers, Hauppauge, NY, USA 2008.

14. WASILEWSKI M. Methodology for carbon footprint calculation. Introduction to methodology for carbon footprint calculation. Ministry of Economy and CSRinfo. 6, 2009 [in Polish].

15. HARTIKAINEN H., ROININEN T., KATAJAJUURI J.M., PULKKINEN H. Finnish consumer perceptions of carbon footprints and carbon labelling of food products. J. Clean. Prod. 73, 285, 2014.

16. WEIDEMA B.P. Carbon footprint - A catalyst for life cycle assessment. J. Ind. Ecol. 12 (1), 3, 2008.

17. COULOMB D. Refrigeration and cold chain serving the global food industry and creating a better future: two key IIR challenges for improved health and environment. Trends Food Sci. Tech. 19, 413, 2008.
18. CUCEK L., KLEMES J., KRAVANJA Z. A Review of Footprint analysis tools for monitoring impacts on sustainability. J. Clean. Prod. 34, 9, 2012.

19. EVANS J.A., FOSTER A.M., HUET J.-M., REINHOLDT L., FIKIIN K., ZILIO C., HOUSKA M., LANDFELD A., BOND C., SCHEURS M., VAN SAMBEECK T.W.M. Specific energy consumption values for various refrigerated food cold stores. Energy Build. 74, 141, 2014.

20. FANG K., HEIJUNGS R., DE SNOO G.R. Theoretical exploration for the combination of the ecological, energy, carbon, and water footprints: Overview of a footprint family. Ecol. Indic. 36, 508, 2014.

21. FLICK D., HOANG H.M., ALVAREZ G., LAGUERRE O. Combined deterministic and stochastic approaches for modelling the evolution of food products along the cold chain. Part I: Methodology. Int. J. Refrig. 35, 907, 2012.

22. GARNETT T. Cooking up a storm - Food, greenhouse gas emissions and our changing climate. UK: Food Climate Research Network, University of Surrey, 2008.

23. WIEDMANN T. A first empirical comparison of energy footprints embodied in trade - MRIO versus PLUM. Ecol. Econ. 68, 1975, 2009.

24. WIEDMANN T. Editorial: carbon footprint and input-output analysis - an introduction. Econ. Sys. Res. 21, 175, 2009.

25. JIANYI L., YUANCHAO H., CUI S., JIEFENG K., XU L. Carbon footprints of food production in China (1979-2009). J. Clean. Prod. 90, 97, 2015.

26. KRISTENSEN T., SØEGAARD K., ERIKSEN J., MOGENSEN L. Carbon footprint of cheese produced on milk from Holstein and Jersey cows fed hay differing in herb content. J. Clean. Prod. 2015 [in Press].

27. RAMÍREZ T., MEAS Y., DANNEHL D., SCHUCH I., MIRANDA L., ROCKSCH T. Water and carbon footprint improvement for dried tomato value chain. J. Clean. Prod. 2015 [in Press].

28. TUROWSKI J., TKACZ K. The carbon footprint - an innovative index of the environmental impact of the food chain. The work and materials of the Gdansk University, Faculty of Management. Product quality and safety and environmental protection in the agriculture and food sector. 2 (1), 399, 2010 [in Polish].

29. WIĘK A., TKACZ K. Carbon Footprint: an ecological indicator in food production. Pol. J. Environ. Stud. 22 (1), $53,2013$.

30. ROBERTSON K., SYMES W., GARNHAM M. Carbon footprint of dairy goat milk production in New Zealand. J. Dairy. Sci. 98 (7), 4279, 2015. 